\title{
A current view of copybooks (the font) in the Czech Republic and in selected countries of Europe
}

\author{
Iva Košek Bartošová ${ }^{1 a}$, Anna Plovajková ${ }^{1}$, and Tereza Podneckác ${ }^{1}$ \\ ${ }^{1}$ Institute of Primary and Pre-primary Education, Faculty of Education, University of Hradec Králové, \\ Rokitanského 62, 50003 Hradec Králové, Czech republic
}

\begin{abstract}
The purpose of the present research of mixed design, i.e. qualitative and quantitative nature is to draw a comparison of the most widely used copybooks - textbooks in the Czech Republic based on adapted evaluation criteria originally presented by [1] - content, graphic design, format and adequacy of writing tasks and range etc. and subsequently focus the research on an analysis of similar workbooks copybooks (including the used font) in selected European countries. The proposed research project is a follow-up of a research project realized in 2014 and designed to identify the publishing houses having the greatest numbers of sales of textbooks for 1st -3rd grades of primary schools as well as the reasons for which teachers choose the materials from a particular publishing house in the Czech Republic.
\end{abstract}

Keywords: Elementary literacy; reading literacy; workbooks; font; comparative analysis

\section{Introduction}

Discussions of education in contemporary literature or media often include terms such as literacy pre-literacy, e-literacy, reading literacy or functional literacy, whose meanings are not completely clear to the lay public. Almost all of them encompass a set of skills necessary for reading and writing and developing gradually before school attendance [2] as well as a complex of skills and the ability to use written speech in communication, education, entertainment etc. in the course of the whole life [3].

Textbooks and copybooks (workbooks) are didactic materials or aids facilitating the acquisition of the skills needed in the given areas of education. The purpose of copybooks is the acquisition of basic writing skills, i.e. handwriting.

Unlike in countries such as China, in European countries pupils learn to write phonetic scripts. Languages using the Latin phonetic script, which developed from the Greek script

\footnotetext{
${ }^{\text {a }}$ Corresponding author: iva.kosekbartosova@uhk.cz
} 
about 500 years B.C. include: English, Spanish, Portuguese, French, German, Italian, Javanese, Azerbaijani, Latin, Czech, Vietnamese and many others.

We intend to use the data obtained through questionnaires during last year research as well as data from literature to carry out an analysis of the most widely used copybooks in the Czech Republic (printed by the publishing houses Nová škola, Alter, Fraus, Studio 1+1, Didaktis), focusing on their content, graphic design, format, adequacy of the texts and space for the needs of pupils with early writing skills. Partial results were published in spring 2015 at the ICASSR conference in China. The present contribution uses the limited space in this publication to briefly present a qualitative-quantitative view of the copybooks (workbooks) in selected European countries.

\section{Theoretical Basis}

Research on textbooks is conducted by many foreign experts, research projects and presented in many journals. A number of professional texts can be found e.g. in JSTOR, EBSCO, ProQuest 5000 etc. Greger [4] mentions the existence of establishments specialising in research on textbooks (e.g. Georg-Eckert-Institute fur internationale Schulbuchforschung, the Norvegian Centre for Pedagogical Texts and Learning Processes, the Australian TREAT - Teaching Resources and Textbook Research Unit at the University of Sydney. An international coordination and information base for all countries is provided, among others, by IARTEM (International Association for Research on Textbooks and Educational Media) who organises an international conference every two years (the 2015 conference is held in Berlin, Germany). In the Czech Republic, the issue is the domain of the "Skupina pro výzkum kurikula (Curriculum research group)" at the Institute of Research for School Education of the Faculty of Education at Masaryk University (IRSE) focussing on the quality and evaluation criteria of textbooks. The area of workbooks copybooks has been paid little attention so far. An evaluation of workbooks for 1st graders at primary schools was done by Turečková [5] from the Masaryk University in Brno and Ventová [6] from Charles University in Prague.

\section{Research objectives and design}

The study objective was to make a comparison of the most widely used textbooks copybooks in the Czech Republic, their differences concerning qualitative features, fonts and the content and to compare them with foreign workbooks. We were interested in the differences between copybooks - workbooks, but also in the type of the cursive script in the most commonly used copybooks published by different houses in the Czech Republic and in the differences between workbooks in the Czech Republic and selected European countries.

\subsection{Methods and research sample}

The mixed method design has been the natural choice in pedagogical research since its inception. This approach consists in combining qualitative and quantitative methods and techniques of data collection and analysis in dependence on the research question (Skutil et al. [7] the current discussion concerning mixed method design deals with its rich terminology, which is in the process of establishing itself in the Czech Republic as well as abroad).

This mixed method design is used in the present research, i.e. the qualitative and quantitative views are combined. It is a so called analysis that is based on comparing the 
qualities of two different phenomena / works / systems etc. and it is applicable in various fields such as sociology, political science, economy, literary science or pedagogy and others, the specific procedures being slightly different in each field. The methods of analysing workbooks - copybooks in the first year of primary schools will be based on evaluation criteria focusing on: content, graphic design, format (size), diversity of texts (adequacy, types of writing tasks) and the number of different copybooks in the set for the first graders produced by the same publishing house in the Czech Republic. We also focused on a comparison of letter shapes and copybooks in selected countries.

The research sample is represented by the data concerning the workbooks and copybooks in use and obtained through questionnaire survey, in which 614 respondents primary school teachers were involved, plus an analysis of the most widely used copybooks published by Nová škola, Alter, Fraus, Studio 1+1, Didaktis, SPN (Prodos). The analysis of material from abroad was based on copybooks from the following countries: Belgium, England, Spain, Portugal, Slovenia, Bulgaria and Lithuania.

\subsection{Research results}

The specific research realized in 2014 brought information on the most widely used copybooks in the Czech Republic (Fig 1). According to our respondents, the most widely used copybooks as well as textbooks are produced by the following publishing houses: Nová škola (49 \%), Alter (14\%), Fraus (7\%), Studio 1+1 (7\%), Didaktis (6\%), SPN (4\%) and Prodos $(3 \%)$.

The most common reason for the selection of copybooks ( $26 \%$ of respondents) was that they were published by the same house as the textbook (Fig. 1). The respondents' evaluations of the materials include mainly content and didactic qualities, followed by range and graphic design. Regrettably, $7 \%$ of pedagogues are not free to choose a particular copybook based on their own consideration. The individual comparisons have been already published.

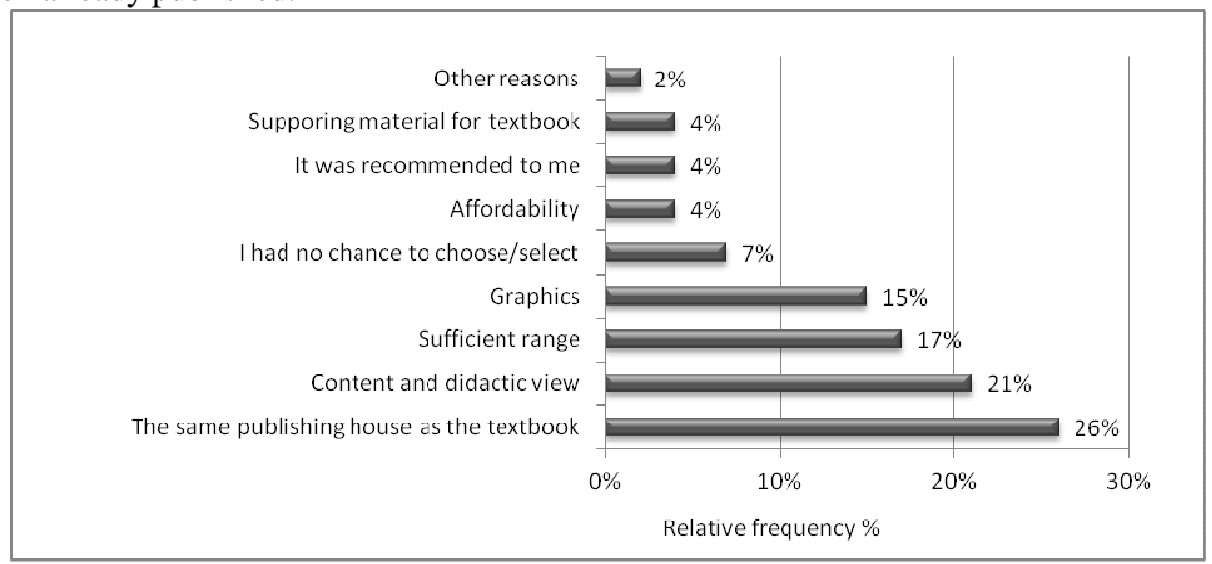

Fig. 1 Reasons for selecting workbooks for teaching elementary writing

We would like to present another comparison carried out within the wider research and concerning the letters which the pupils learn to write first in the first year of primary schools in the Czech Republic. The publishing houses Studio 1+1, Alter, Nová škola and Didaktis exclude the letters $q, Q, w, W, x, X$ from copybooks for the first year. Alter also excludes $Y$. The rest of the publishing houses include all letters in copybooks for the first 
year. The table below shows the ten letters that pupils learn to write first in the order corresponding to the order in the copybooks (Table 1).

Table 1. The first ten letters according to the order of acquisition

\begin{tabular}{lllllll}
\hline $\begin{array}{l}\text { Nová } \\
\text { skola }\end{array}$ & Alter & Fraus & $\begin{array}{l}\text { Studio } \\
1+1\end{array}$ & Didak. & SPN & Prodos \\
\hline $\mathrm{e}$ & $\mathrm{E}$ & $\mathrm{l}$ & $\mathrm{L}$ & $\mathrm{e}$ & $\mathrm{e}$ & $\mathrm{i}$ \\
$\mathrm{l}$ & $\mathrm{I}$ & $\mathrm{m}$ & $\mathrm{E}$ & $\mathrm{i}$ & $\mathrm{i}$ & $\mathrm{u}$ \\
$\mathrm{m}$ & $\mathrm{U}$ & $\mathrm{p}$ & $\mathrm{I}$ & $\mathrm{u}$ & $\mathrm{l}$ & $\mathrm{e}$ \\
$\mathrm{i}$ & $\mathrm{M}$ & $\mathrm{s}$ & $\mathrm{U}$ & $\mathrm{m}$ & $\mathrm{u}$ & $\mathrm{a}$ \\
$\mathrm{u}$ & $\mathrm{T}$ & $\mathrm{t}$ & $\mathrm{A}$ & $\mathrm{l}$ & $\mathrm{m}$ & $\mathrm{o}$ \\
$\mathrm{a}$ & $\mathrm{L}$ & $\mathrm{e}$ & $\mathrm{O}$ & $\mathrm{s}$ & $\mathrm{s}$ & $\mathrm{m}$ \\
$\mathrm{s}$ & $\mathrm{A}$ & $\mathrm{j}$ & $\mathrm{M}$ & $\mathrm{p}$ & $\mathrm{t}$ & $\mathrm{j}$ \\
$\mathrm{o}$ & $\mathrm{o}$ & $\mathrm{i}$ & $\mathrm{T}$ & $\mathrm{t}$ & $\mathrm{p}$ & $\mathrm{l}$ \\
$\mathrm{p}$ & $\mathrm{s}$ & $\mathrm{n}$ & $\mathrm{P}$ & $\mathrm{j}$ & $\mathrm{j}$ & $\mathrm{s}$ \\
$\mathrm{t}$ & $\mathrm{p}$ & $\mathrm{u}$ & $\mathrm{S}$ & $\mathrm{a}$ & $\mathrm{a}$ & $\mathrm{v}$ \\
\hline
\end{tabular}

Nová škola, Alter and Studio 1+1 all begin with the same ten letters. The order of the first four letters is the same in Alter and Didaktis, the letters being $e, i, u, m$. The letter which is usually taught first is $e$ [8].

We chose the lower-case $z$ and $v$ to be presented here (Table 2) as a sample comparison (the complete comparison covered the whole alphabet).

Table 2. A comparison of writing practice: $\underline{z}$ and $\underline{\underline{v}}$ in copybooks from different publishing houses

\begin{tabular}{|l|l|l|l|}
\hline & ALTER & & DIDAKTIS \\
\hline 4 & DIDAKTIS & & FRAUS \\
\hline 4 & FRAUS & PRODOS \\
\hline & PRODOS & & SPN \\
\hline
\end{tabular}

The differences in the shape of the letter $z$ in copybooks from the publisher Alter are noticeable at the first sight. The first difference concerns the first curve, which does not bend inwards. Furthermore, Alter is the only publishing house in whose copybooks the top stroke of $z$ is not identical to the top stroke of $r$. Also, the pupils do not learn to write the loop at the bottom, which is very prominent in the $z$ from the publishing house Didaktis. The shape of $z$ in the copybooks from Alter is based on the original shape from the previous century designed by Václav Penc. The typographers from the other publishing houses introduced innovations, i.e. made the letter narrower and the shapes sharper.

Lowercase $v$ is also worth mentioning (Table 2). There is perceptible difference in the shape of the loop at the top as well as the width of the letter. These differences are prominent especially in the case of Didaktis and Fraus. The shape of $v$ in Didaktis is wider and the loop is bigger. The width of the $v$ in Prodos is similar to Didaktis, while Fraus and SPN have a narrower shape of $v$.

The analysis involved a comparison of letter shapes as well as the preparation exercises, i.e. practising certain curves before writing whole letters. Obviously, an important part of each set of copybooks is an exercise book with relaxation exercises for the development of graphomotory skills. The publishing houses Nová škola, Alter, Studio 1+1, Didaktis and Prodos have a whole exercise book with relaxation exercises, while SPN has only several pages of the first volume in the set for this purpose. As for the format, SPN is the only publishing house having the A5 format, the other publishing houses have A4 formats. 
Due to the limited space, it is impossible to present the entire research, which is quite extensive. The following section mentions some of the foreign workbooks and differences in letter shapes, mainly in the case of the cursive script. A manuscript has been introduced recently into selected schools in the Czech Republic; however, this new script is not the focus of the present research.

We had the opportunity to compare foreign copybooks of one publisher from each of the following countries: Lithuania, Belgium, England, Slovenia, Portugal and Spain. All the copybooks except those from Lithuania and Belgium, which are close to A5 format, are in A4 format.

The Lithuanian copybook has at least one picture at most of the pages. The margins as well as parts of the pictures are colored (Fig. 2). The writing practice proceeds from tracing the letters on the first line to getting independent on the second line and writing on one's own on the third.

The Belgian copybook is different in that all the double pages look similar and each has a given topic, such as human body, toys, weather, fruit, animals etc. The double page begins with a picture and a poem. There are multiple lines in the whole copybook; however, there is no line to indicate the height of tall letters (e.g. $k$ ). In the middle of the copybook there is a sheet with stickers, which the children can stick in place of pictures in one color.

The English copybook is pleasant to look at. Page margins are colored and there are also many colored pictures. (Fig. 3) Similarly to the Lithuanian copybook, there are red dots indicating where to write the letter or a word. The greater part of the copybook has multiple lines, there are lines indicating the height of small as well as tall letters. There are copying exercises only.

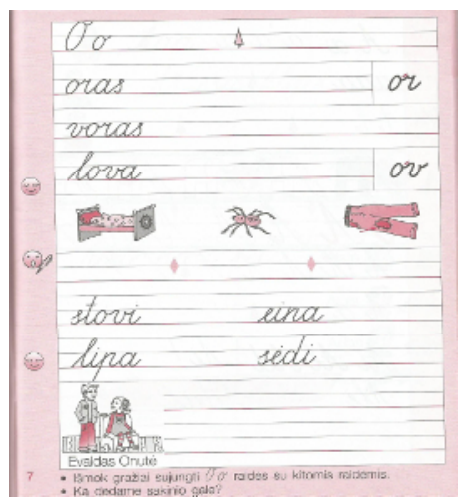

Fig. 2 A page from Lithuanian copybook

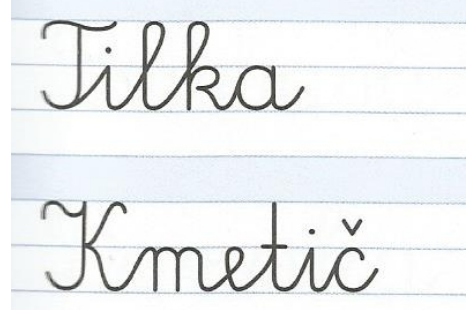

Fig. 4 Multiple lines, Lili in bine, Slovenia

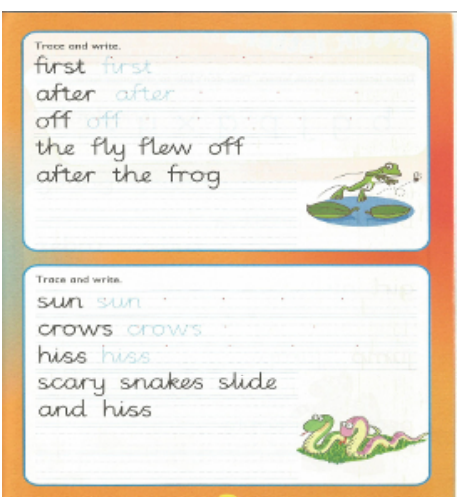

Fig.3 A page from English copybook

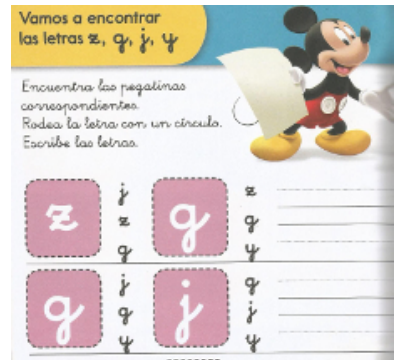

Fig. 5 A page from Spanish copybook

The Slovenian publishing house (Fig. 4) Klett, Lili in bine produces colored copybooks full of illustrations teaching to write uppercase and lowercase manuscript letters. The final 
part of the first copybook is dedicated to the cursive script. There are tasks such as writing a word below a picture, drawing a picture according to a word or choosing a word to match a picture. Multiple lines are in the manuscript section as well as the cursive section. The Klett publishing house has recently begun to publish copybooks and textbooks for the Czech Republic as well.

An interesting aspect of the Portuguese copybooks is that one volume contains vowels and numbers, while the other one has syllables and the practice consists in tracing printed words.

The Spanish copybook is very colorful and Disney cartoon characters guide the children through the practice (Fig. 5). At the end, there is a sheet with stickers to be stuck on the practice pages, which is similar to the Belgian copybook. The copybook also includes a certificate for the pupils, task key and colored circles and cards with letters which can be cut out and used to play Bingo. The repeated types of tasks are: tracing of letters copying of letters, matching pictures with the same letter. There are multiple lines in the whole copybook.

Due to the limited space, we only present some of the features and properties of the analysed copybooks. We also compared the shapes of letters in the individual countries. The pictures below show some of them without further analysis (Table 3 - 4).

Table 3. Letter o

\begin{tabular}{|c|c|}
\hline & Slovenia \\
\hline & Portugal \\
\hline & $\begin{array}{c}\text { Czech } \\
\text { Republic }\end{array}$ \\
\hline
\end{tabular}

Table 4. Letter

\begin{tabular}{|c|c|}
\hline 94 & Portugal \\
\hline$M$ & Slovenia \\
\hline$M$ & $\begin{array}{c}\text { Czech } \\
\text { Republic }\end{array}$ \\
\hline
\end{tabular}

\subsection{Summary}

The results of the analysis presented above shows in which aspects the sets of copybooks printed by Czech publishers differ (the number of volumes per grade, practice methods, copybooks format as well as slight deviations in letter shapes). The comparison with foreign workbooks (from England, Belgium, Portugal, Spain, Slovenia and Lithuania) also reveals differences in letter shapes, joining techniques, format of the workbooks and their graphic design. Similarly to the Czech Republic, the type of script (manuscript vs. cursive script) is under discussion e.g. in Great Britain. The English copybook teaches a script similar to our manuscript writing, however, the letters are joined together. Still, the letters b. $g, j, p, q, x, y, z$ are never joined with the following ones. Furthermore, the letters are perpendicular to the line. Small cursive letters in the Slovenian copybook Lili in bine are closest to the cursive letters taught in the Czech Republic. Naturally, there are certain exceptions; the letters $o$ and $c$ begin at the line unlike in Belgium where the writing begins in the space between the lines. The letters in the Portuguese copybook are very similar to our manuscript letters as well; there are differences in the inclination of letters, the Portuguese letters being more perpendicular. The joining of letters in Lithuania is similar to the Czech Republic as well. 


\section{Conclusion}

Research results showed that there are differences in the handwriting practice both within one country (e.g. the Czech Republic) as well as between different European countries. These differences concern the graphic design as well as the content, the format and ways of teaching (the use of multiple lines, sample letters etc.). A surprising finding is the lack of marked differences in letter shapes in the analysed copybooks. As for the cursive script, there are no prominent differences in letter joining.

Our intention was to present in brief an extensive research dealing with copybooks and workbooks in the Czech Republic (different publishers) as well as in selected European countries and comparing the copybooks (workbooks) as well as letter shapes, their size, joining and last but not least the ways of handwriting practice.

This paper presents results of the Specific Research Project of University of Hradec Králové number 2112 named: Comparative Analysis of Copybooks (font) used in the Czech Republic and in selected European countries.

\section{References}

1. Maňák, J., \& Knecht, P., Evaluation of books. Brno: Paido, p. 141, (2007).

2. Kucharská, A., Riziko dyslexie. - Pregramotnostní dovednosti a rozvoj gramotnosti v rizikových skupinách (The Risk of Dislexia - Pre-lieracy skills and the development of Literacy in High-risk Groups). Praha: PedF UK, (2014).

3. Najvarová, V., Čtenářské strategie žáků prvního stupně základní školy. Pedagogická orientace (Reading Strategies of Pupils in Primary Schools. A Pedagogical perspective.), 20(3), pp. 49-65, (2010).

4. Greger, D. Přehled výzkumů učebnic v zahraničí (An Overview of the textbook research abroad). In maňák, J.; Klapko, D. (eds.). Učebnice pod lupou. Pedagogický výzkum v teorii a praxi (Textbooks under the Magnifying Glass. The Theory and Practice of Pedagogical Research). Brno: Paido, pp. 23-32, (2006).

5. Turečková, J., Učebnice a cvičebnice pro výuku elementárního psaní (Textbooks and Workbooks of Elementary Writing). Brno: PdF. [diplomová práce/ MA thesis], (2010).

6. Ventová, K., Reformy psacích abeced pro nejmenší. Je čas na změnu? (Reforms in Handwriting Alphabets for the Youngest Pupils. A time for change?). Praha: PedF UK. [diplomová práce/ MA thesis], (2010).

7. Skutil, M. a kol., Základy pedagogicko-psychologického výzkumu pro studenty učitelství (The Basics of Pedagogico-psychological Research for Student Teachers). Praha: Portál, p. 256, (2011).

8. Košek Bartošová, I., Plovajková A.,\& Podnecká T., Development of Reading Literacy Based on the Work of Textbooks (Workbooks). Procedia - Social and Behavioral Sciences, vol. 171, pp. 668-679, (2015). 